\title{
MACHINE NOISE INTENSITY AND WORKERS STRESS LEVEL OF JEWELRY FACTORY IN SURABAYA
}

\author{
Amelia Cyntia), Sadya Wendra ${ }^{2)}$, Inge Wattimena ${ }^{3)}$
}

\begin{abstract}
Introduction: Noise in the work environment can cause negative effects for workers. Working with uncomfortable conditions over time will cause stress. Stress caused by noise can be increased if not handled seriously

Aim: This study is aimed to analyze the correlation between machine noise intensity and workers' stress level of jewelry factory in Surabaya.

Methods: This research use analytic survey with type of research design used is cross sectional research design. The population in this study involved 110 production employees in the jewelry factory in Surabaya in 2017. Sampling technique in this research is nonprobability sampling that is purposive sampling or judgmental sampling. Respondents who met the inclusion criteria were 87 people. The intensity measurement of noise is using the Sound Level Meter on each machine that is in the production section 3 times then counted on average. The measurement of job stress is using a validated questionnaire. Spearman correlation test has done to know correlation between variables.

Result: There is a significant and strong positive relationship $(p=0.000, R=0.696)$ between machine noise intensity and workers' stress level of jewelry factory in Surabaya. Conclusion: This study showed that the higher the intensity of engine noise, the higher the level of stress generated. Education through Health Promotion is important to do in all industry sectors using voiced machines for better worker's welfare.
\end{abstract}

Keywords: Machine noise intensity, Stress level, Workers

\footnotetext{
${ }^{1)}$ Student of Faculty of Medicine Widya Mandala Catholic University Surabaya, Kalisari Selatan 1 Surabaya Email : Ameliacyntia@gmail.com

${ }^{2)}$ Psychiatry Department Faculty of Medicine Widya Mandala Catholic University Surabaya, Kalisari selatan 1 Surabaya

${ }^{3)}$ Public Health Department Faculty of Medicine Widya Mandala Catholic University Surabaya, Kalisari selatan 1 Surabaya
} 


\section{INTRODUCTION}

Technological developments have shown remarkable progress in the modern era as it is today. Many aspects of the life sector have used the existence of technology itself. Its presence has given a considerable impact on human life in various aspects and dimensions. The use of machinery and hazardous materials has also increased. The Occupational Safety and Health (Keselamatan dan Kesehatan Kerja or K3) system that is launched in the industrial sector is still weak, so it has an impact on the health of the workforce. The Ministry of Manpower of the Republic of Indonesia in 2013 stated that the level of work accidents and various $\mathrm{OSH}$ threats in Indonesia was still quite high in the production process. Based on the 2013 International Labor Organization report, work accidents resulting in fatal fatalities of approximately 6,000 cases every day. While in Indonesia, in every 100,000 workers, there are 20 fatalities due to work accidents [1]. Occupational Health and Safety (Keselamatan dan Kesehatan Kerja or K3) is science and its application in an effort to prevent the possibility of accidents and occupational diseases that have the aim of protecting the workforce at work so that safety and health are always guaranteed so that it can be realized increased production and work productivity, protecting everyone else who are in the workplace are always safe and sound and protect materials and production equipment so that they are used safely and efficiently [1].

Occupational safety and health is one aspect of labor protection by applying control technology to all aspects that have the potential to endanger workers. Control is also aimed at sources that have the potential to cause illness due to this type of work. It is necessary to prevent accidents and harmonize work equipment or machinery, and the characteristics of the people who carry out the work and the people around them. An uncomfortable work environment, such as noise, is one of the factors that can cause health problems [2].

Threshold Value (Nilai Ambang Batas or NAB) is the level that can be faced by workers without showing health problems or the emergence of disease or abnormalities in daily work. The standard quality standard allowed is $85 \mathrm{dBA}$, and the maximum working time is 8 hours per day [3]. Noise is an unwanted sound whose duration, intensity, and quality cause various impacts on the physiology or psychology of humans and other creatures.

Noise, in addition to causing deafness, will also have other negative impacts on 
health that can ultimately interfere with work. Working with uncomfortable conditions over time will cause stress and fatigue [4].

A survey conducted by Northwestern National Life on workers in America in 2012 showed that $40 \%$ of workers reported experiencing stress at work. The survey also stated that $25 \%$ of workers who work in noisy places claimed to experience very severe stress [5].

Stress can affect health in two ways. First, changes caused by stress directly affect the physical system of the body that can affect health. Second, stress indirectly affects individual behavior so that it causes illness or worsens existing conditions [6].

Stress and noise can have negative effects, so we feel the need to examine the relationship between machine noise intensity and stress levels in factory workers.

\section{RESEARCH METHOD}

The population in this study were all active employees in the production of jewelry factories in Surabaya in 2017, as many as 110 people, the number of samples used was 87 people.

Inclusion criteria include officially registered as an active jewelry factory employee in Surabaya, working in the production department, working for 8 hours, under 40 years of age, working more than five years, not having a history of ear disorders, willing to be a research sample. The sampling technique in this study is a non-probability sampling that is purposive sampling or judgmental sampling. In this purposive sampling or judgment sampling, we choose the respondent based on subjective and practical considerations, that the respondent can provide sufficient information to answer the research question.

Noise intensity measurements are carried out using a Sound Level Meter when the production process at the factory is in progress. Each measurement must be able to represent a certain time interval by setting at least four measurement times [7]. Noise intensity can be categorized as very quiet if the noise level is $0-20$ decibels, quiet if the noise level is $21-40$ decibels. In contrast, the noise level is 4160 decibels, loud if the noise level reaches 61-80 decibels, very loud if the noise level is $81-100$ decibels, very loud when the noise level is 101-201 decibels, and deafening if it is above 120 decibels [8].

Measurement of work stress is obtained through primary data. We use primary data collection in the form of distributing questionnaires to factory workers to determine the level of stress on 
workers. The questionnaire consisted of several questions, which were physical, psychological, and behavioral symptoms of work stress. Respondents gave yes or no answers to every physical, psychological, and behavioral symptom. The assessment of this questionnaire is, the researcher will give a value of 1 for each answer yes and a value of 0 for each answer no. The total score will be categorized into three, namely, mild stress with a total score of $0-6$, moderate stress with a total score of 7-13, while severe stress with a total score of 14-19. The questionnaire used was tested for validity and reliability using SPSS 22, and it was proven that the questionnaire was valid and reliable. From 30 questions raised by researchers, there are 19 valid questions. The reliability testing technique used is the Alpha Cronbach reliability coefficient. The reliability results obtained based on the Alpha Cronbach reliability coefficient amounted to 0,716 . This instrument can be said to be reliable because of the value of alpha> 0.6 [9].

Table 1 Questions before Validation

\begin{tabular}{llc}
\hline Questions & $\begin{array}{c}\text { Question } \\
\text { Number }\end{array}$ \\
\hline Physical & Headache & 1 \\
Symptoms & Fatigue & 2 \\
& Easily Shocked & 3 \\
& Stomachache & 4 \\
& Constipation & 5 \\
& Shortness of & 6 \\
& breath & \\
& Sweating hands & 7
\end{tabular}

and feet

Mouth and 8

esophagus feels

dry

Decreased

appetite

Stiff back neck $\quad 10$

to back

Total Physical Symptoms Questions: 10

\begin{tabular}{|c|c|c|}
\hline \multirow{11}{*}{$\begin{array}{l}\text { Psychological } \\
\text { Symptoms }\end{array}$} & Forgetful & 11 \\
\hline & Hard & 12 \\
\hline & Concentrate & \\
\hline & Indecisive & 13 \\
\hline & Anxious & 14 \\
\hline & Oftenly crying & 15 \\
\hline & Uneasy & 16 \\
\hline & Desperation & 17 \\
\hline & Insomnia & 18 \\
\hline & $\begin{array}{l}\text { Loss of } \\
\text { creativity }\end{array}$ & 19 \\
\hline & $\begin{array}{l}\text { Loss of passion } \\
\text { in appearance }\end{array}$ & 20 \\
\hline \multicolumn{3}{|c|}{ Total Psychological Symptoms Questions: 10} \\
\hline \multirow{13}{*}{$\begin{array}{l}\text { Behavior } \\
\text { Symptoms }\end{array}$} & Withdraw from & 21 \\
\hline & $\begin{array}{l}\text { social } \\
\text { interaction }\end{array}$ & \\
\hline & Eager to fight & 22 \\
\hline & Smoking & 23 \\
\hline & $\begin{array}{l}\text { Alcohol } \\
\text { drinking }\end{array}$ & 24 \\
\hline & $\begin{array}{l}\text { Easy to blame } \\
\text { people }\end{array}$ & 25 \\
\hline & Stubborn & 26 \\
\hline & $\begin{array}{l}\text { Often absence } \\
\text { in work }\end{array}$ & 27 \\
\hline & $\begin{array}{l}\text { Abnormal } \\
\text { eating behavior }\end{array}$ & 28 \\
\hline & Anger & 29 \\
\hline & Management & \\
\hline & Issues & \\
\hline & $\begin{array}{l}\text { Not satisfied } \\
\text { with what was } \\
\text { achieved }\end{array}$ & 30 \\
\hline
\end{tabular}

Table 2 Questions after Validation

\begin{tabular}{lll}
\hline & $\begin{array}{l}\text { Questions } \\
\text { before } \\
\text { Validation }\end{array}$ & $\begin{array}{l}\text { Questions } \\
\text { after } \\
\text { Validation }\end{array}$ \\
\hline Physical & $1,2,3,4,5,6$, & $1,2,3,6,9$ \\
Symptoms & $\begin{array}{l}7,8,9,10 \\
\text { Total: } \mathbf{1 0}\end{array}$ & Total: $\mathbf{5}$ \\
Psychological & $11,12,13,14$, & $11,12,16,17$, \\
Symptoms & $15,16,17,18$, & 19,20 \\
& 19, 20, 21, 22 & \\
& $\begin{array}{l}\text { Total: 12 } \\
\text { 23, 24, 25, 26, }\end{array}$ & Total: $\mathbf{6}$ \\
Behavior & & \\
\hline
\end{tabular}




\begin{tabular}{lll}
\hline Symptoms & $27,28,29,30$ & $26,28,29,30$ \\
& Total: 8 & Total: 8 \\
& Whole Total: & Whole Total: \\
& $\mathbf{3 0}$ & $\mathbf{1 9}$ \\
\hline
\end{tabular}

\section{RESULT}

Table 3 Respondent Distribution based on Age

\begin{tabular}{ccc}
\hline Age & $\begin{array}{c}\text { Frequency } \\
\text { (people) }\end{array}$ & $\begin{array}{c}\text { Percentage } \\
(\%)\end{array}$ \\
\hline Under 40 y/o & 97 & 88.1 \\
$\geq 40 \mathrm{y} / \mathrm{o}$ & 13 & 11.9 \\
\hline Total & 110 & 100 \\
\hline
\end{tabular}

Based on Table 3, it can be seen that respondents aged under 40 years are 97 people with a percentage of $88.1 \%$ while those aged $\geq 40$ years are 13 people with a percentage of $11.9 \%$.

\section{Respondent Distribution based on Work Term}

Table 4 Respondent Distribution based on Work

\begin{tabular}{ccc}
\hline Work Term & $\begin{array}{c}\text { Frequency } \\
\text { (people) }\end{array}$ & $\begin{array}{c}\text { Percentage } \\
(\%)\end{array}$ \\
\hline $0-5$ y/o & 15 & 13.6 \\
Above 5 y/o & 95 & 86.4 \\
\hline Total & 110 & 100 \\
\hline Term
\end{tabular}

Based on Table 4, it can be seen that respondents who worked 0-5 years were 15 people with a percentage of $13.6 \%$ while those who worked above 5 years were 95 people with a percentage of $86.4 \%$.

Respondent Distribution based on History of Ear Disorders
Table 5 Respondent Distribution based on History of Ear Disorders

\begin{tabular}{ccc}
\hline $\begin{array}{c}\text { History of } \\
\text { Ear Disorders }\end{array}$ & $\begin{array}{c}\text { Frequency } \\
\text { (people) }\end{array}$ & $\begin{array}{c}\text { Percentage } \\
(\%)\end{array}$ \\
\hline Positive & 6 & 5.4 \\
Negative & 104 & 94.6 \\
\hline Total & 110 & 100 \\
\hline
\end{tabular}

Based on Table 5, it can be seen that respondents who have a history of ear disorders are 6 people with a percentage of $5.4 \%$ while those who do not have a history of ear disorders are 104 people with a percentage of $94.6 \%$.

\section{Respondent Distribution based on Machine Type}

Table 6 Respondent Distribution based on Machine Type

\begin{tabular}{ccc}
\hline Machine Type & $\begin{array}{c}\text { Frequency } \\
\text { (orang) }\end{array}$ & Percentage (\%) \\
\hline Clustering & 15 & 13.6 \\
Soldering & 22 & 20 \\
Ice cutting & 12 & 10.9 \\
Grinding & 10 & 9.1 \\
Laser & 8 & 7.3 \\
Sandpaper & 10 & 9.1 \\
Polishing & 16 & 14.5 \\
Vibrator & 7 & 6.4 \\
Hammer & 10 & 9.1 \\
\hline Total & 110 & 100 \\
\hline
\end{tabular}
Based on Table 6 , it can be seen that there are 15 people working on clustering machines with a percentage of $13.63 \%$, while soldering machines have 22 workers with a percentage of $20 \%$, on ice cutting machines there are 12 workers with a percentage of $10.90 \%$, there are 10 workers on the grinding machine with a percentage of $9.09 \%$, on the laser machine there were 8 workers with a percentage of $7.28 \%$, on the sandpaper machine there were 10 workers with a percentage of 
$9.09 \%$, on the polishing machine there were 16 workers with a percentage of $14.55 \%$, while on the vibrator machine there were 7 workers with a percentage of $6.37 \%$, and on a hammer machine there are 10 workers with a percentage of $9.09 \%$.

\section{Distribution of Engine Noise Intensity Measurement}

Based on Table 7, it can be seen that the clustering machine has a noise intensity of 55 decibels on the first measurement. In contrast, the second measurement has a noise intensity of 55 decibels, on the third measurement has a noise intensity of 56 decibels. From the average of the three measurements, the noise intensity of the clustering machine is obtained, which is 55.33 decibels. Clustering machines can be in the category of machines that have moderate noise intensity.

\begin{tabular}{cccccc}
\hline $\begin{array}{c}\text { Machine } \\
\text { Type }\end{array}$ & $\begin{array}{c}1^{\text {st }} \\
\text { Measurement } \\
(\mathrm{dB})\end{array}$ & $\begin{array}{c}2^{\text {nd }} \\
\text { measurement } \\
(\mathrm{dB})\end{array}$ & $\begin{array}{c}3^{\text {rd }} \text { Measurement } \\
(\mathrm{dB})\end{array}$ & $\begin{array}{c}\text { Average } \\
\text { Measurement } \\
(\mathrm{dB})\end{array}$ & Explanation \\
\hline Clustering & 55 & 55 & 56 & 55.33 & Medium \\
Soldering & 58 & 57 & 58 & 57.67 & Medium \\
Ice cutting & 72 & 74 & 71 & 72.33 & Loud \\
Grinding & 76 & 73 & 75 & 74.67 & Loud \\
Laser & 79 & 79 & 78 & 78.67 & Loud \\
Sandpaper & 87 & 89 & 88 & 88 & Very Loud \\
Polishing & 89 & 88 & 88 & 88.33 & Very Loud \\
Vibrator & 89 & 90 & 90 & 89.67 & Very Loud \\
Hammer & 92 & 96 & 95 & 94.33 & Very Loud \\
\hline
\end{tabular}

Table 7 Distribution of Engine Noise Intensity Measurement

Clustering machines can be in the category of machines that have moderate noise intensity. Soldering machine has a noise intensity of 58 decibels on the first measurement, on the second measurement has a noise intensity of 57 decibels, on the third measurement has a noise intensity of 58 decibels, from the average of the three measurements obtained 57.67 decibels. Soldering machines can be categorized as machines with moderate noise intensity. Ice cutting machine has a noise intensity of 72 decibels on the first measurement, on the second measurement has a noise intensity of 74 decibels, on the third measurement has a noise intensity of 71 decibels, from the average of the three measurements obtained 72.33 decibels. Ice cutting machine can be categorized as a machine with loud noise intensity. Grinding machine has a noise intensity of 76 decibels on the first measurement, on the second measurement has a noise intensity of 73 decibels, on the third 
measurement has a noise intensity of 75 decibels, from the average of the three measurements obtained 74.67 decibels. Grinding machines can be categorized as machines with loud noise intensity. The laser machine has a noise intensity of 79 decibels on the first measurement, on the second measurement has a noise intensity of 79 decibels, on the third measurement has a noise intensity of 78 decibels, from

The sanding machine can be categorized as a machine with very loud noise intensity. The polishing machine has a noise intensity of 89 decibels on the first measurement; the second measurement has a noise intensity of 88 decibels, the third measurement has a noise intensity of 88 decibels, from the average of the three measurements obtained 88.33 decibels. Polishing machines can be categorized as machines with deafening noise intensity. Vibrator machine has a noise intensity of 89 decibels on the first measurement, the second measurement has a noise intensity of 90 decibels, on the third measurement has a noise intensity of 90 decibels, from the average of the three measurements obtained 89.67 decibels. Vibrator machines can be categorized as machines with very loud noise intensity. The hammering machine has a noise intensity of 92 decibels on the first measurement, on the second measurement has a noise the average of these three measurements obtained 78.67 decibels. Laser machines can be categorized as machines with loud noise intensity. Sandpaper machine has a noise intensity of 87 decibels in the first measurement, the second measurement has a noise intensity of 89 decibels, in the third measurement has a noise intensity of 88 decibels, from the average of the three measurements obtained 88 decibels.

intensity of 96 decibels, on the third measurement has a noise intensity of 95 decibels, from the average of the three measurements it was found 94.33 decibels. The hammer engine can be categorized as a machine with very loud noise intensity.

\section{Distribution of Stress Symptoms}

\section{Sequence experienced by 87 Workers}

Table 8 Distribution of Stress Symptoms Sequence experienced by 87 Workers

\begin{tabular}{llcc}
\hline No & Stress Symptoms & $\begin{array}{c}\text { Freqeuncy } \\
\text { (people) }\end{array}$ & $\begin{array}{c}\text { Percentage } \\
(\%)\end{array}$ \\
\hline 1 & Fatigue & 52 & 59.8 \\
2 & Hard to concentrate & 44 & 50.6 \\
3 & Headache & 42 & 48.3 \\
4 & Smoking & 41 & 47.1 \\
5 & Anxious & 40 & 46 \\
6 & Forgetful & 38 & 43.7 \\
7 & Not satisfied with & 38 & 43.7 \\
& what was achieved & 35 & 40.2 \\
8 & Easily Shocked & 35 & 40.2 \\
9 & Anger Management & 34 & 39.1 \\
& Issues & 33 & 37.9 \\
10 & Desperation & 32 & 36.8 \\
11 & Eager to fight & 32 & 36.8 \\
12 & Decreased appetite & 32 & 36.8 \\
13 & Loss of creativity & Abnormal eating & 33.3 \\
14 & behavior & 29 & 31 \\
15 & Shortness of breath & 27 &
\end{tabular}




\begin{tabular}{|c|c|c|c|}
\hline No & Stress Symptoms & $\begin{array}{c}\text { Freqeuncy } \\
\text { (people) }\end{array}$ & $\begin{array}{c}\text { Percentage } \\
(\%)\end{array}$ \\
\hline 17 & Stubborn & 27 & 31 \\
\hline 18 & $\begin{array}{l}\text { Loss of appearance } \\
\text { passion }\end{array}$ & 25 & 28.7 \\
\hline 19 & $\begin{array}{l}\text { Withdraw from social } \\
\text { interaction }\end{array}$ & 25 & 28.7 \\
\hline
\end{tabular}

The most physical symptoms

experienced by respondents were fatigue with a frequency of 52 people (59.8\%). The most psychological symptoms experienced by respondents were difficult to concentrate with a total frequency of 44

\begin{tabular}{|c|c|c|c|c|}
\hline $\begin{array}{l}\text { Machine } \\
\text { Type }\end{array}$ & $\begin{array}{l}\text { Noise } \\
\text { Intensity }\end{array}$ & $\begin{array}{l}\text { Mild } \\
\text { Stress }\end{array}$ & $\begin{array}{l}\text { Medium } \\
\text { Stress }\end{array}$ & $\begin{array}{l}\text { Heavy } \\
\text { Stress }\end{array}$ \\
\hline Clustering & Medium & 12 & 2 & 0 \\
\hline Soldering & Medium & 16 & 3 & 0 \\
\hline Ice cutting & Loud & 4 & 4 & 0 \\
\hline Grinding & Loud & 3 & 7 & 0 \\
\hline Laser & Loud & 0 & 8 & 0 \\
\hline Sandpaper & Very loud & 0 & 7 & 0 \\
\hline Polishing & Very loud & 1 & 4 & 0 \\
\hline Vibrator & Very loud & 0 & 6 & 0 \\
\hline Hammer & Very loud & 0 & 7 & 3 \\
\hline \multicolumn{2}{|c|}{ Total } & 36 & 48 & 3 \\
\hline \multicolumn{5}{|c|}{ people $(50.6 \%)$. The most behavioral } \\
\hline
\end{tabular}

\section{Distribution of Respondents' Stress Degrees}

Table 9 Distribution of Respondents' Stress Degrees

Berdasarkan tabel 9 dapat diketahui bahwa pekerja yang bekerja dengan Based on Table 9, it can be seen that workers who work using a clustering machine with medium noise intensity, there are 12 workers who experience mild stress and two workers who experience moderate stress. Workers who work using soldering machines that have medium noise intensity, 16 of them experience mild stress while three others experience medium stress. Workers who work using an ice cutting machine that has a loud noise intensity, four workers experience mild stress, and four other workers experience medium stress. Workers who work by using a grinding machine that has a loud noise intensity, three workers experience mild stress, and seven other workers experience medium stress. Workers who work using a laser machine that has an intensity of loud noise, eight workers experience medium stress. Workers who work using sandpaper machines that have very loud noise intensity, seven workers experience medium stress. Workers who work using a polishing machine that has a very loud noise intensity, one worker experiences mild stress, while four others experience medium stress. Workers who work using vibrator machines that have very loud noise intensity, six workers experience medium stress. Workers who work using hammer machines that have very loud noise intensity, seven workers experience medium stress, and three others experience heavy stress.

\footnotetext{
Analysis of Machine Noise Intensity and Stress Level in Jewelry Factory Workers in Surabaya
} 
Table 10 Analysis of Machine Noise Intensity and Stress Level in Jewelry Factory Workers in Surabaya

\begin{tabular}{llll}
\hline & & Noise & Stress \\
\hline Noise & Correlation & 1.000 & $.696^{* *}$ \\
& $\begin{array}{l}\text { Coefficient } \\
\text { Sig.(2-tailed) }\end{array}$ & & \\
& N & 87 & .000 \\
Stress & Correlation & $.696^{* *}$ & 1.000 \\
& Coefficient & & \\
& Sig.(2-tailed) & .000 & \\
& N & 87 & 87 \\
\hline
\end{tabular}

*Analyzed by Spearman $(\alpha=5 \% ; 2$-tailed significance)

Based on Table 10, it can be seen that there is a correlation between the intensity of engine noise with the stress level with a p-value of 0,000 , where the alpha value used is 0.05 so that $p<\alpha=$ related. The statistical correlation strength was 0.696 , showing a strong correlation between the intensity of machine noise and stress levels in jewelry factory workers in Surabaya [46].

\section{DISCUSSION}

The study was conducted to determine the correlation between engine noise intensity and stress levels. We researched one of the jewelry factories in Surabaya. The location of the research at one jewelry factory in Surabaya was chosen because after conducting an initial survey, it was found that many machines were needed by the jewelry factory for the production process with varying noise intensity. We also found that there are some prominent symptoms of work stress, which are more than 15 employees out of
30 employees often feel tired, shortness of breath, dry mouth and throat, decreased appetite, stiff neck, difficulty sleeping, irritability, often blame other people. Also, there are many times there have been quarrels with people around the worker.

The type of research we used was an analytical survey while the research design used in this study was cross sectional with a population of all active employees in the production of jewelry factories in Surabaya in 2017, as many as 110 people. The sample used was workers who met the inclusion criteria of the researchers and were taken with a purposive sampling technique. The inclusion criteria set by the researchers are officially registered as active jewelry factory employees in Surabaya, working in the production department, working for 8 hours, under 40 years of age, working more than 5 years, having no history of ear disorders, and willing to be a research sample. There were 87 respondents who met the inclusion criteria.

The study was conducted on June 6,2017 . The research was conducted by giving directions and explanations to workers regarding the research to be conducted by researchers. The researcher also shared an agreement statement that was signed by respondents who were willing to be the subject of the study. 


\section{Characteristics of Respondents}

The variables that will be discussed by researchers include, age, length of work, and ear disorders. We categorize the respondent's age into two categories namely those under 40 years of age and more than 40 years old. The age category is taken from the theory of the effect of age on hearing that from the age of 40 there is an increase in the hearing threshold. We obtained data from filling out the questionnaire that there were $11.9 \%$ or 13 people out of 110 people aged 40 years and over 40 years, while those under 40 years were $88.1 \%$ or 97 people.

We categorize the respondent's work term into two categories: respondents who work 0-5 years and respondents who work for more than five years. The work term category is adjusted to the theory of the effect of work time on stress. The theory explains that workers who have worked for more than five years have a higher saturation level than new workers. This means that the saturation level of workers at work can cause stress at work [39]. Data obtained from the results of the study showed that there were $86.4 \%$ or 95 people out of 110 people who worked over five years, while there were $13.6 \%$ or 15 people out of 110 people who worked 0-5 years.
We categorize respondents who have experienced ear problems and have never had an ear problem. We categorize ear disorders because if there is a disturbance in the ear, it makes the patient more resistant to noise because the sound entering the ear becomes reduced [24]. We found that there were six respondents out of 110 respondents who filled out a questionnaire where the six respondents had ear problems, so they did not meet our inclusion criteria.

\section{Noise Intensity}

We measured the intensity of engine noise three times on each machine at $08.30,11: 30$, and 14:30. The machines whose noise intensity is measured are machines in the production section, namely clustering machines, soldering machines, ice cutting machines, grinding machines, laser machines, sandpaper machines, polishing machines, vibrator machines, and hammer machines. The results obtained from the measurement of noise intensity on each machine are taken on average, and the results become noise intensity on the machine. Measurement of engine noise intensity is by the theory of noise intensity measurement, i.e., each measurement must be able to represent a specific time interval by setting at least four-time measurements [9]. Noise intensity measurements are carried out while the production process is in 
progress by using a Sound Level Meter (SLM). Noise intensity is divided into several categories, namely very quiet if the noise level is $0-20$ decibels, quiet if the noise level is 21-40 decibels. In contrast, the noise level is 41-60 decibels, loud if the noise level reaches 61-80 decibels, very loud if the noise level 81100 decibels, very loud when the noise level is 101-201 decibels, and deafening if above 120 decibels. We get three categories from machine noise intensity measurement results, namely medium noise intensity for clustering and soldering machines, loud noise intensity for ice cutting machines, grinding machines, and laser machines and very loud noise intensities for sandpaper machines, polishing machines, vibrator machines, and hammer machines.

The limit that can be faced by workers without showing health problems or the emergence of disease or abnormalities in daily work is often referred to as the Threshold Value (Nilai Ambang Batas or NAB). NAB, according to Minister of Manpower Decree No. 51 of 1999 for workers, is 85 decibels, while the time for workers is 8 hours a day. The results obtained by researchers are a sandpaper machine with an average noise intensity of 88 decibels, a polishing machine with an average noise intensity of 88.33 decibels, a vibrator machine with an average noise intensity of 89.67 , and a hammer machine with an average noise intensity of 94.33 that have exceeded the Value Threshold set by Minister of Manpower Decree No. 51 of 1999.

\section{Work Stress}

Measurement of stress levels in workers is obtained through a questionnaire distributed to workers. The questionnaire consisted of several questions, which were physical, psychological, and behavioral symptoms of work stress. The stress level questionnaire distributed to workers has passed the validity and reliability test conducted by researchers using SPSS 22 .

We divide stress into three categories, namely mild stress, moderate stress, and heavy stress. The division of stress categories is taken from a questionnaire that contains the symptoms of work stress that includes physical, psychological, and behavioral symptoms. The questionnaire containing 19 questions was distributed to respondents to be given a yes or no answer. We give a value of 1 for each yes answer and a value of 0 for every no answer. Then we categorize stress into three, namely mild stress with a score of $0-6$, medium stress with a total score of 7-13, and heavy stress with a total score of 14-19. Three jewelry factory workers work in the production section 
experience heavy stress, 48 workers who experience medium stress, and three workers who experience mild stress.

Physical symptoms of work stress experienced by jewelry factory workers who work in the production department are 42 respondents who experienced headaches, 52 respondents felt fatigued, 35 respondents were easily shocked, 29 respondents experienced shortness of breath, and 32 respondents experienced decreased appetite.

Psychological symptoms of work stress experienced by factory workers are 38 forgetful respondents, 44 respondents have difficulty concentrating, 40 respondents experience anxiety, 34 respondents despair, 32 respondents experience loss of creativity, and 25 respondents experience loss of passion for appearance.

Behavioral symptoms of work stress experienced by factory workers are 25 respondents withdrawing from social interaction, 33 respondents easily quarreling, 41 respondents smoking, 27 respondents easily blaming others, 27 respondents are stubborn, 32 respondents have behavior eating abnormally, 35 respondents were irritable, and 38 respondents were dissatisfied with what they had achieved.

The results of this study are in line with the results of research from Nadhiroh
MH [10] regarding the correlation of noise exposure with work stress on labor at PT. Triangga Dewi Surakarta in the weaving section, which is part of weaving from yarn into raw cloth, obtained an average noise in the weaving section of 100.15 decibels. The results of the study showed that 15 workers (39.47\%) experienced mild stress, 20 workers $(52.63 \%)$ experienced medium stress, and three workers $(7.89 \%)$ experienced severe stress. Workers who work for 8 hours a day with 30 minutes of rest at that location complain of dizziness, nausea, fatigue, lack of concentration, and insomnia, which are symptoms of work stress.

The results of this study are also in line with the results of research conducted by Budiyanto T, Pratiwi EY [4], in the weaving company "Agung Saputra Tex" located in Yogyakarta. In research with machines that have 99 decibels, it is found that employees feel tired, dizzy, less comfortable at work, employees who hear everyday noise for a long time feel disturbed emotional well-being, such as irritation faster.

Research conducted by Gaol RPL [11] results are in line with the results of our study. From these studies, they obtained average noise in the Power House section of PT. Humbahas Bumi Energy is $95 \mathrm{dBA}$ (exceeding the $85 \mathrm{dBA}$ 
threshold value). The results of the assessment of occupational stress symptoms showed that three workers (25\%) experienced mild stress symptoms, seven workers $(58.3 \%)$ experienced medium levels of stress symptoms, and two workers $(16.7 \%)$ experienced levels of heavy stress symptoms.

Workers who work using a Workers who work using a clustering machine with medium noise intensity, 12 workers experience mild stress, and two workers who experience medium stress. Workers who work using soldering machines that have medium noise intensity, 16 of them experience mild stress, while three others experience medium stress. Workers who work using an ice cutting machine that has a loud noise intensity, four workers experience mild stress, and four other workers experience medium stress. Workers who work using a machine that has an intensity of loud noise, three workers experience mild stress, and seven other workers experience medium stress. Workers who work using a laser machine that has an intensity of loud noise, eight workers experience medium stress. Workers who work using sandpaper machines that have very loud noise intensity, seven workers experience medium stress. Workers who work using a polishing machine that has a very loud noise intensity, one worker experiences mild stress, while four others experience medium stress. Workers who work using vibrator machines that have very loud noise intensity, six workers experience moderate stress. Workers who work using a hammer machine that has a very loud noise intensity, seven workers experience moderate stress, and three others experience severe stress.

\section{Correlation between Noise Intensity and Work Stress}

We tested the research hypothesis using the Spearman test, and the results obtained $p$-value $=0.00$, where the alpha value used was 0.05 . So if the p-value is smaller than the alpha value, it means that there is a correlation between the intensity of engine noise and the stress level [12]. The results of this study are under the theory that one non-auditory effect caused by noise in the work environment is an increased incidence of stress [6]. Statistical correlation strength is 0.696 , which shows a strong relationship between machine noise intensity and stress levels in jewelry factory workers in Surabaya [12]. 
From the results of this study, we succeeded in achieving the general goal of this study, which is to find out whether there is a relationship between the intensity of machine noise and stress levels in jewelry factory workers in Surabaya. We can also know that the higher the intensity of engine noise, the higher the stress level. We got rid of hypothesis 0 because of the results of this study found a relationship between the intensity of machine noise and stress levels in jewelry factory workers in Surabaya. In this study, we see that the factory has provided ear protection devices such as earplugs and ear muffs in sufficient quantities to be used by workers. However, the majority of workers do not wear these ear protection devices. This results in the intensity of noise received by labor directly without any effort to reduce the noise received by workers. Lack of awareness of the importance of using earplugs or ear muffs increases the risk of stress for these workers.

\section{Research Limitations}

This study has limitations in that all workers are given a questionnaire and do not distinguish workers who use selfprotection devices (earplugs or ear muffs) because research respondents sometimes use self-protection devices, sometimes do not use self-protection equipment. This research only looks at work stress through 19 work stress questions that have been tested for validity, not looking at other factors that can cause job stress.

\section{CONCLUSION}

Based on the results of research conducted on the correlation of machine noise intensity and stress levels in jewelry factory workers in Surabaya to 87 samples in June, we concluded that the working time at the jewelry factory had met the time limit allowed. However, the noise intensity on some machines exceeded the intensity limit noise allowed. The maximum working time is 8 hours per day, and the permitted quality standard is $85 \mathrm{dBA}$.

We got three categories of noise intensity through measurements using a Sound Level Meter, namely medium, loud, and very loud noise intensity. Stress in workers is also categorized by researchers into three categories, namely mild stress, moderate stress, and heavy stress. The results showed that the higher the intensity of engine noise, the higher the stress level produced.

The results of the statistical tests show a correlation between the intensity of machine noise with stress levels in jewelry factory workers in Surabaya. The strength of the correlation statistically 
shows a strong relationship between the intensity of machine noise and stress levels in jewelry factory workers in Surabaya.

Occupational Safety and Health (Keselamatan dan Kesehatan Kerja or K3) is one aspect of labor protection, which in the industrial sector in Indonesia is still weak and has an impact on the health of the workforce. The results of this study are useful and informative in conducting education through Health Promotion to achieve worker welfare.

\section{REFERENCES}

1. Yanri Z. Kumpulan peraturan perundangan di bidang kesehatan kerja. Depnakertrans. Jakarta; 2002

2. Marji. Dampak kebisingan terhadap pekerja pabrik pada berbagai latar belakang tingkat pendidikan. Malang : Gunung Samudera; 2013

3. Kemenakertrans RI, Permenakertrans No. 13/MEN/X/2011 Tentang nilai ambang batas faktor fisika dan faktor kimia di tempat kerja, Jakarta; 2011

4. Budiyanto T, Pratiwi EY. Hubungan kebisingan dan masa kerja terhadap terjadinya stres kerja pada pekerja di bagian tenun "Agung Saputra Tex Piyungan Bantul Yogyakarta. Skripsi: Program Studi Ilmu Kesehatan Masyarakat Universitas Ahmad Dahlan Yogyakarta; 2010

5. Sari R. Hubungan intensitas kebisingan dengan tingkat stres kerja pada pegawai di PT. Kereta Api Indonesia DAOP IV Semarang. Skripsi: Program Studi Ilmu Kesehatan Masyarakat Universitas Negeri Semarang; 2011

6. Rusjadi D. Konsep dasar akustik. Yogyakarta: Graha Ilmu; 2015

7. Suharsono H. Dampak pada udara dan kebisingan. Bahan Kuliah AMDAL. PPLH-IPB, Bogor; 1991

8. Tigor. Kebisingan di tempat kerja. Yogyakarta: Andi; 2009

9. Harrianto R. Buku ajar kesehatan kerja, Jakarta: EGC; 2010

10. Nadhiroh MH. Hubungan paparan kebisingan dan stres kerja pada tenaga kerja di bagian weaving PT. Triangga Dewi Surakarta. Skripsi: Program Studi Ilmu Kesehatan Masyarakat Univeritas Sebelas Maret Surakarta; 2011

11. Gaol RPL. Hubungan kebisingan dengan gejala stres kerja di bagian power house di PT. Humbahas Bumi Energi Kabupaten Humbang Hasundutan. Skripsi: Program Studi Ilmu Kesehatan Masyarakat Universitas Sumatra Utara; 2014

12. Dahlan MS. Statistik untuk kedokteran dan kesehatan, Ed. 6. Jakarta: Epidemiologi Indonesia; 2014 